\title{
Online Language Learning for Thai EFL Learners: An Analysis of Effective Alternative Learning Methods in Response to the Covid-19 Outbreak
}

\author{
Pongpatchara Kawinkoonlasate ${ }^{1}$ \\ ${ }^{1}$ English Department Faculty of Liberal Arts, Huachiew Chalermprakiet University, Samut Prakarn, Thailand \\ Correspondence: Pongpatchara Kawinkoonlasate, English Department Faculty of Liberal Arts, Huachiew \\ Chalermprakiet University, Samut Prakarn, Thailand.
}

Received: October 12, 2020

doi: $10.5539 /$ elt.v13n12p15
Accepted: November 3, 2020

Online Published: November 10, 2020

URL: https://doi.org/10.5539/elt.v13n12p15

\begin{abstract}
Online language learning had already been an increasingly popular and useful method of language acquisition prior to spike in demand for alternative learning methods brought upon by the Covid-19 pandemic. As a tool that allows learning to continue without undue risk of exposure to the virus, it has increasingly become a new normal for students around the world, and Thai EFL learners specifically. As online learning has become more widely used in response to this worldwide plight, it has become accepted as an important tool and approach that can overcome the inherent dangers and limitations present in on-campus learning. This has become accepted in educational institutions around the world and is no less true for the Thai educational system. Educational technology (EdTech) has made significant progress in recent years, moving far beyond the simple ability of communication with your professor allowed by email and more recent systems of online assignment submissions. As the sophistication of EdTech advancements grows, it's applications can be used to expand the reach and approachability of lessons beyond a formal classroom environment; thereby, increasing both the motivation and effectiveness of the learner. Modern teaching philosophy, across all subjects, actively encourages the incorporation of technology to aid in the facilitation of optimum teaching delivery. This is especially important for those teaching a new language (for our purposes, English to Thai learners), as these technological tools can facilitate greater understanding in an environment where the language barrier is otherwise an impediment. This paper looks to further analyze the effectiveness of online learning methods and tools, for both the instructors and the language learners. Furthermore, this paper will propose and review methods to integrate and use this technology in the classroom or other learning environment available. As distance learning is becoming a more prevalent methodology due to the untenable nature of holding class in enclosed, densely packed, spaces (i.e., your standard classroom), knowing more of both the technologies and their effectiveness in a language learning environment is of paramount importance. In this paper, the terms online instruction and integration are widely used and their use in the context of language learning is provided. This paper also explores the EdTech and devices relevant to the discussion and provides explanations of their use. To provide a proper foundation, we will also be discussing prior literature and findings pertaining to the use of technology in the context of English language learning. This paper will also provide and discuss the reaction and results obtained from online language learners using the proposed medium. These results were gathered from a combination of recorded online observations and measured learning outcome objectives. From the combination of material provided, studied, and analyzed, this paper concludes with a presentation of potential methods that may help instructors improve the English language acquisition of their students.
\end{abstract}

Keywords: effectiveness, technology in education, online instruction, language learning

\section{Introduction}

EdTech has been changing what technology can and should be used for education at a rapid pace. What seems to be simple now (i.e. the submission of assignments online), would have been unthinkable a mere thirty years ago. This technology has improved and changed the way we communicate and collaborate on a daily basis, making cooperation possible in a way inaccessible to the vast majority of people only a decade ago. Study materials, such as textbooks or books were having historically been prohibitively expensive and until recently only the "elite" truly had regular access to educational opportunities. Technology (including the internet) is having a profound 
impact on traditional educational practices and learning environments, challenging many of the assumptions made about the way the industry must operate as a whole. This is a system that has been traditionally isolated, and collaboration has typically been limited to other learners in the same physical space (Online Purdue, 2020). Technology has not only changed the accessibility education; it has also begun to transform the roles of those within the educational system (the instructors and learners) (Ahmadi, 2018). As such, technology has proven to be a powerful tool that supports and transforms the way we interact with education in a myriad of ways.

Technological devices are making it easier for instructors to design educational material, providing new ways for learners to learn and work together, and so much more. With the global reach provided by the internet and the wide availability of mobile devices that can connect to it, a new age of anytime-anywhere education is upon us. This new age, and the direction is takes, will rely upon both those designing and providing education and the new powerful tools they can and should use to enhance the education provided. If this opportunity is grasped, using the increasingly available technology to change how we educate, effective education will be increasingly be available around the world (Online Purdue, 2020). This change should, by all rights, be an easy one to pursue as developing technology has always been an important part of the educational environment. Educators are all taught that they should use whatever tools are the most appropriate and viable to facilitate their learners' learning. English language acquisition in the Thai educational environment often emphasizes that subject mastery is beneficial for both communication and business. This language mastery is providing an economic competitiveness in the globalized era and provides further opportunities for lifelong education. The English as a foreign language (EFL) or English as a second language (ESL) classrooms selected for this paper focus on English skills development.

These classrooms motivate their learners to not stop their educational pursuits at the door of the classroom, and explain how increasing their exposure through the online learning medium will further develop their English language skills and increase content knowledge. These classrooms explain how this is useful for their future academic and economic pursuits. The classroom herein refers to English reading and writing courses offered in the academic years of 2019 and 2020. The learners referenced throughout are sophomores who have been taught with an online learning platform. Monumental changes to both the methods and facilities used in the current educational environs has been imposed due to precautions taken in light of the global COVID-19 pandemic. With high infection rates, long periods of time where the infected are contagious, a high mortality rate, and a myriad of other issues, concerns relating to the COVID-19 pandemic has required a sudden, and often jarring, change in the way most aspects of life are conducted, education being only one of many aspects heavily impacted. Most countries have had to take drastic action by closing those places where people congregate together, such as schools, colleges, universities, restaurants, bars, sporting venues, and other businesses. This pandemic has created a situation where people of all stages and walks of life have had to adapt, and quickly. Educators are no different in this regard and also must adapt and provide solutions and design suitable teaching methods that adapt to the material they are responsible for.

Online learning platforms have become instrumental to the design and implementation of these courses. Herein, the author intends to discuss and the methods by which language instructors can and should tailor their educational offering to the technology available and share developmental methodology that can be used to prepare the learners for education delivered through online learning and via the available technological devices in the midst of this pandemic. As is necessary in these times, lessons and activities which were previously considered a safe and viable educational delivery method (that of teaching a roomful of learners in a closed room in close proximity to one another), have been adjusted to reduce the risk learners are exposed to. This is done by delivering educational information through online learning systems, rather than through traditional methods (Swan, 2019; Suminar, 2020). Over the course of the course in English reading and writing, the learners studied through online classes, and practiced their lessons after class alone. The majority of the learners felt nervous at the onset of the course; however, the learners were able to familiarize and adapt to the new "normal" teaching method and they began to enjoy their learning anew.

One way the most important methods to reduce the impact of Covid-19 and slow the spread is through the practice of social and physical distancing. This practice limits the spread of the virus by preventing people from coming within the understood transmissible range of the virus. Instructors, staff, and learners are expected to work from home; however, they are still expected to carry out their duties and responsibilities. The use of social and physical distancing methods to curb the virus has greatly affected what is or is not considered a safe and viable learning method. Thereby greatly diminishing the feasibility of traditional teaching models. The adoption of online learning, adaptation to new technology in the classroom, and necessity of remote instruction has had a significant impact on both instructors and learners, though in different ways. This necessary adaptation to an online class experience has proven to have both benefits and limitations. These aspects of online learning will require adaptations which will 
impact the process of learning as we currently understand it. As such, the university's policy is to offer English language courses through online learning technology. Through this policy, the university must ensure that the undergraduate Thai EFL learners of the affected semester(s) are using online learning media that is appropriate for learners' background knowledge level. This paper will present a variety of technological tools that can be used to facilitate online language learning, potential selections of online learning platforms, and discuss the effectiveness of these.

\section{Technology and Technological Integration in Education}

The use of technology in both the acquisition and teaching of a foreign language is proving to be more and more beneficial for all parties involved. Modern standards of living presume an integration a significant amount of informational and communication technology into our daily activities. From paying bills to obtaining directions to communicating plans with our peers, the way we plan and live our lives depends upon our use of said technologies. Even without the need to adapt to the situation created by COVID-19, it is only natural that the way we access language instruction and learning match our increasing utilization of digital technology. To facilitate this, teachers and students should be able to not only use the target language at the appropriate level (English in our case), but they should also be able to use and thrive with the additional technology applied to the learning environment. EdTech was already becoming an increasingly important and valuable part of instructors and learners' lives (from communicating with the instructor through email to accessing course documents on a shared server to more modern applications of document submission and other virtual classroom tools). This increasing importance didn't start with the necessary adjustment to the COVID-19 pandemic, but the dire necessity of the use of these technologies definitely increased. In response to these trends, computers, laptops, tablets, mobile phones, and $\mathrm{Wi}-\mathrm{Fi}$ connections are increasingly necessary to facilitate and participate in language instruction. The Ministry of Education in Thailand is increasingly supporting projects and programs that aim to bring new approaches to teaching a variety of subjects, including EFL (Babacan \& Gunuc, 2017). As such, the importance of technological integration and technology use in education was already an important factor for the future development of classroom instruction in Thailand. The need to quickly adapt to the realities brought upon us by COVID-19 simply turned this important factor to a necessary one.

\subsection{Overview of Online English Language Learning}

Even prior to the oft referred catalyst mentioned throughout this paper, online language learning had been a growing industry in its own right and wan being used more frequently in more traditional educational institutions. Hockly (2015) defines online language learning as language learning that takes place fully online, via the internet without a face-to-face component. Kasteen (2014) states that online instruction has become a prominent part of second language learning and shares that it is often referred to as computer assisted language learning. This paper takes the position that online learning has become an increasingly central aspect of education with the advent of the COVID-19 pandemic, providing both advantages and exposing limitations in the instruction/learning process. This increased focus on online learning comes from the global need to adapt instruction/learning away from traditional teaching methodology and structures that currently pose a significant health risk to an online learning methodology that removes significant risk and takes advantage of the technology that already pervades our lives. The teaching experience earned through 7 years of university level English reading and writing instruction, has provided insight to the author of this paper that online learning is more learner-centered as learners are able to take control of their own learning pace. Furthermore, the types of instructional interactions can be flexible enough to better suit the learner's preferred learning style. Online learning also has the advantages that it creates more chances for active learning, learners have greater freedom of learning as the learner does not have to adhere to a specific class schedule, and classroom attendance is not required. These conditions should prove useful when designing the course and specific instruction material for EFL learners. The following sections will discuss how to specifically use technological applications and tools in online instruction and learning.

\subsection{Technology Use in Online Language Instruction}

Technology has the proven to be a powerful and transformative tool for teaching by ushering in a new, more connected, model of teaching. Learning English, like other educational goals, has been shown to be much more effective when combined with appropriate educational technology. The increasing use of modern technology in the learning environment helps to link instructors to their learners, to professional content, resources, and to systems designed to help improve their own lessons and personalize learning (Mofareh, A., 2019). Studies show that teaching programs that involve the aforementioned technological tools have become the preference of instructors, since they appear to correlate with positive learners' engagement with the instructors/instructional material and incentivizes overall English language acquisition (Ahmadi, 2018). 
With modern technology not only being useful for language acquisition, but also favored by instructors and learners alike, evidence seems to promote the increased use of these advancements even when external influences (COVID-19), do not necessitate them. While these specific changes may not always be necessary, it is a necessity that educational institutions continue to revolutionize their methods and continuously explore and develop better ways to provide education to learners. To this goal, it would be wise to utilize what the global technological revolution provides by adopting modern technological means such as computerization, multi-media devices, mobile phones, audio and/or visual effects applications, and social media, all of which is already integrated into most learners' daily lives. This would serve to further optimize English language instruction and provide the instructors with additional avenues to connect with classroom language learners in a systematic and advanced way. This author's experience with Thai EFL learners has provided compelling evidence that learners' use of technology as a significant part of their learning process enhances the overall experience and boosts the retention of information.

Learners commonly use technology such as the internet to search for more information related to their courses or studies both while inside and outside the classroom. Knowing that learners already have an inclination to use some technology to assist their instruction, instructors should ensure that the curriculum itself is designed in such a way as to take advantage of and promote this use of technology to support the learning objectives and boost the learners' language acquisition. The study by Pourhossein Gilakjani (2017) showed that the application of technology plays an important role in both promoting activities for learners and promotes a positive adaptation for the instructors' teaching methods. As such, technological devices have shown to play a positive role in promoting the engagement of learning activities, promoting initiative for the learners, and boosting the overall teaching effect in the English class.

Prior studies have already shown that EdTech promotes both improved engagement and perceived enjoyment of the learning materials used; however, further studies show that there are significantly more benefits to the incorporation of further technology. The related effects that have also been shown to occur with the use of EdTech is an increase in learner motivation and social interactions related to the material being taught (Parvin \& Salam, 2015; Pourhossein Gilakjani, 2017; Ahmadi, 2018). This paper postulates that EdTech allows learners to adjust the learning process to one they feel best suits their own needs. Furthermore, the expectation that technology is an integral part of the learning process promotes the access of information that their instructors may not be able to provide. Technology is also making collaborative learning more possible, varied, and enriching than ever before. Collaborative learning promotes activities in which the learners cooperatively work together to create tasks or assignments and learn from each other. Collaborative learning is another methodology shown to improve both engagement and retention of instructional material.

A combination of this methodology with modern technological tools shown to promote the same metrics, is expected to, and anecdotally does, yield compounding improvements on these metrics. Indeed, this author's own class observations, has provided evidence that a technology-enhanced teaching environment is more effective than purely lecture-based class. While these observations are promising, it is important to note that instructors should offer multiple methods of applying technology as a learning instrument, as educators are no doubt aware, different learners will respond better to different methods. Additionally, educators must be mindful that some learners have not been exposed to or had the same opportunity to learn technology as their peers. As such, it is vital that educators ensure that all learners have the opportunity to become proficient with technology to be adopted, and that educators be aware that some are not able to use the new tools as well as their more technologically proficient peers.

While it is important to know that evidence supports the usefulness and beneficial attributes of technology use in language learning, it is also vital to acknowledge the extenuating circumstances that demand immediate consideration of the effects of online learning technology on language acquisition. Thailand, like the majority of the world, is facing and adapting to a particularly contagious and deadly virus that makes traditional learning methods not only obsolete, but dangerously irresponsible to pursue. As such, this university has adopted policy for Thai instructors to design their courses using more modern technology, understanding the following:

1. Technology enables students to develop strong content knowledge through a myriad of sources, and it allows learners to demonstrate independence in pursuit of knowledge.

2. The use of the modern technology (such as radios, TV, computers, the internet, electronic dictionary, mobile devices, email, blogs, audio-visual aids, videos, and DVDs/VCDs) motivates learners to interact with the courses and promotes autonomous learning. 
3. Technology use for educational goals promotes self-sufficiency in the learner that will better equip the learner for future endeavors, either academic or career related.

4. Modern technology deepens the learning experience by using resources and tools that learners are already interested in and using in their daily lives.

Using this framework and understanding, instructors are expected to be able to adapt and design their own educational material using computers, the internet, radio, television, mobile learning, blogs, e-mail, and relevant messaging/communication tools (i.e. Line Application, WeChat, Microsoft Teams, Zoom program, Loom program, Google Classroom). As has been noted in multiple stories discussing the world's adaptation to these crises, both Microsoft Teams and the Zoom program have become increasingly popular methods to conduct virtual group meetings (whether for a business or a classroom). These tools have been shown to be suitable for learners to learn and discuss the topics presented in an environment that simulates the personal interactions available in the classroom. These programs also provide many additional functions that can be used to facilitate and design the course (such as sharing slides and handouts, recording, and uploading the files).

As is the case in a more traditional classroom, the combination of multimedia and appropriate teaching methodology is very important to keep the learners' engaged and to improve English language retention. As has been mentioned previously, the combination of these technological tools and collaborative teaching methodologies appears to be particularly useful. When planning and designing the course, the instructors should select suitable technological devices to utilize and teach with a well-planned and explained classroom setting. This should provide the learners to integrate the new methods more seamlessly and help the learners to begin learning more efficiently. In addition, the instructors should explore and discover which methods of applying technology are the most useful as a learning instrument for their learners and their particular learning environment. As has been alluded to previously, an appropriate implementation of technology to conduct the class should result in positive results from the students as technology integrated methods have been shown to be more effective than more traditional ones (Mareco, 2017). It is important that instructors are aware; however, that a variety of tools and methods must be used to keep the material engaging and keep the lessons productive (Patel, 2013). While technology and its integration in the classroom has the potential to surpass the effectiveness of more traditional methods, language learners' will always respond better to material that is more interesting and stimulating.

\subsection{Technological Tools of Online Language Instruction}

A primary adaptation involved in moving from a traditional classroom to an online technological one is the search for and use of appropriate EdTech tools needed to develop your new environment. This includes tools for online content creation, content delivery, and tools that encourage students to engage in active learning. Listed below is a curated list and description of tools that have been proven useful for the various activities listed below. This list of tools has been useful for the creation, editing, and presentation of technology-enhanced tasks, activities, and materials useful for online language learning. There are several tools listed below that are available to the online language learners to further facilitate and assist in their educational attainment (Online Teaching Tools and Resources, 2015).

The Yale Centre for Language Study has provided the following categories as important for online teaching, with this author's suggestions for specific useful tools:

a. Video-making: Animoto is useful for simple video making. It is an easy-to-use online tool for creating videos.

b. Podcasting and Voice Recording: Being able to record your voice for your learners is a very powerful tool if used appropriately. Audacity is useful software for recording and editing audio and providing this benefit.

c. Collaborative Working and Writing: Google Docs is a simple, flexible and indispensable tool for collaborative work and editing. The suite of applications can be used for creating, sharing, and collaborating on online documents, spreadsheets, presentations.

d. Presentation Tools: Prezi and Glogster are useful for colorful, brain-friendly presentations. These tools can be exploited for all kinds of interesting lessons that bring course books to life and transform dry curricula.

e. Video conferencing: Zoom, Microsoft Teams, Line, Skype, Facebook, WeChat, and Google Classroom are all useful tools with different individual applications. These are software for text chatting, instant messaging, and video calling. Adapt different tools for your learners' situation. 
f. Learning Platform: Moodle can be a creative learning space if you take time to play with the interface and block features. As an open source platform, it is free and constantly evolving.

Some of the most popular applications or programs for classroom use are Microsoft Teams, Google Classroom, Line, WeChat, Facebook, e-mail, and digital presentation tools (such as Prezi). Most learners are willing and able to use them and access these tools as part of their new educational experience. Much of the increased engagement associated with online learning technologies is because learners are using tools and doing activities that modern learners find more enjoyable as a whole. Interacting with multimedia presentations at their own pace is often more fulfilling to modern learners than the older, more traditional learning methodology such as taking notes for the entire duration of a shared lecture. There has been a plethora of research conducted that provides evidence for the increased engagement and provides speculation for the leading contributing factors for this increased engagement (Parvin \& Salam, 2015; Huang, Yang, Chiang, \& Su, 2016; Song \& Bonk, 2016; Lamb, 2017; Pamintuan, Mallari, Garcia, Galang, \& Buduan, 2018). This author's instructional experience and class observation has led this paper to conclude that the integration of technology in well-designed and well-prepared activities increases motivation of both instructors and learners. This invariably leads to improved instruction performance and better learning results. In direct correlation to the increased engagement as a result of the use of modern technology, learners' language acquisition and retention has been measured to increase. This has been measured both by inference from interaction and from the resulting scores of otherwise similar course material. Learners claimed that they could spend more time to studying and practicing the lessons by themselves and at their own pace.

This paper would be remiss if it were not to acknowledge that some of these benefits could also be a challenge for students that are less able to self-motivate. This is even further complicated by the fact that many of these specific technologies are new to and can be challenging for the learners. The very independence to study by themselves without the instructor's directions that can be so beneficial for some students could prove a challenge for those students that require a more structured learning environment. For a self-motivated student, this technology is a great boon as they have the freedom to more thoroughly study any subject that captures their imagination. While they are able to study any subjects that they are interested in, they are also not forced into a situation to spend time studying something that they are not interested in. So, while there are significant positive effects to consider for using technological devices while teaching and learning, the same positive attributes may provide additional challenges for other learners. For these reasons, the author would like to acknowledge that the full integration of technology for educational purposes should come with an understanding that limitations must still be addressed. The next section looks the integration methods for this technology with language instruction and learning and how to better make use of the benefits and limit the challenges of this integration.

\subsection{Technology Integration for Language Instruction and Learning}

Combined learning, learning management systems and virtual classrooms are examples the modern technology that is being used in Thai education to address the needs presented by the current crises. Ur un (2016) refers to Information and Communications Technology (ICT herein refers to all communication technologies, including the internet, wireless networks, cell phones, computers, software, middleware, video conferencing, social networking, and other media applications and services enabling users to access, retrieve, store, transmit, and manipulate information in a digital form.) as those technologies in which the computer plays a major role. He provides Computer Assisted Language Learning (CALL), the internet, and a variety of common computer applications as examples. Tools that we have already discussed and are commonly used in the implementation of online learning objectives also fall into this category, such as cloud base applications, Twitter, Facebook, WebQuests, games, Microsoft Teams, Zoom, Loom, and mobile devices. While ICT may form a core of the online learning experience, there are many other forms of technology that can be used to support language instructions. Instructors should analyze the individual and specialized needs of their own learners and base the technological selections based upon what they find is most appropriate for their students. For example, not all parents are comfortable with their young children using social media. As such, if the learners in question are young children, social media platform may be considered inappropriate.

One of the biggest draws of integrating more modern technology into the learning process is that technology can create a learning environment that shifts the focus of the class away from the teacher and onto the learner. (Patel, 2013; Arifah, 2014; Pourhosein Gilakjani, 2014; Pourhossein Gilakjani \& Sabouri, 2017) Research has proposed that by using computer technology, language classes become an active place where the learners are responsible for their own learning and are more able to pursue meaningful tasks. In relation to this, Alsaleem (2014) reveals that a computer-based classroom provides a learning experience that increases learners' responsibility for their own education. As has been mentioned before, teaching and learning with technology integrated into the lesson structure supports and assists learners to play a more active role in their education. This helps many learners to 
retain more information, and develop their language skills more efficiently than lecture-based lessons are able to. To best facilitate a successful implementation of these lofty goals the instructor would be best served by creating an implementation plan. This plan should consider integration strategies and know what educational approach is the most effective one for the technologies that have been determined to be most appropriate for the designated group of learners.

The study of Alsaleem (2014) suggested that WhatsApp applications can be used by English learners in dialogue journals to improve the learners' writing, vocabulary, word choice, and speaking ability. A further benefit of using modern technology in the learning environment is that it allows learners to approach educational material from a method that is more useful for themselves. Some students thrive on being able to take notes, others need to use the language to learn it better, and others learn best when acting out scenarios with their peers. Everyone has different methods that allow for the best retention and it is an unfortunate fact that the traditional classroom does not typically have enough time or resources to teach the material in every method. Disli (2012) was able to use an online program to focus on and improve learners' writing skills. This author has found significant success using WeBlog to improve learners' reading skills and found results that mirrored the findings of Noytim (2010). Crane (2012) and Donaldson (2014) argued that teaching tools for teaching and learning with technology or Web 2.0 tools are ideal for students' learning English because they provide them opportunities to use authentic language and be actively engaged in learning by motivating the students to engage with all 4 language uses (listening, speaking, reading, and writing).

The above studies claim that EdTech integration, especially in language instruction, improves traditional classroom techniques and permits learners to use those technological devices that they are already so familiarized with to learn. With so much evidence showing the value of technological integration in conjunction with language acquisition, it seems evident that further development of technologically integrated curriculum would be of significant value to the entire industry. The technology by itself is not sufficient, to reap the rewards proper application for the situation and learner is paramount (Donaldson, 2014). The use of EdTech allows self-pacing, helps in self-understanding, is not detrimental to the interaction between the instructors and learners, and promotes increased engagement in most language learners. As such, it would be in the best interest of both educators and the educational institutions to further develop, integrate, analyze, and improve appropriate technology to be not just a facet of the learners' daily life outside of education, but to also make it a key facet of the educational journey itself.

\section{Learning Achievements through Online Learning}

Online learning has found popularity in Thailand when used in the field of language learning. Distance learning has been an increasingly studied subject, of which online learning has become a predominant facet. In this paper, constructivist theory offers a framework for defining and determining what authentic learning and meaningful content is. The constructivist teacher is described and one who uses methods such as problem-solving and inquiry-based learning activities to provide students with opportunities to formulate and test their ideas, draw conclusions and inferences, and to combine and share their knowledge in a collaborative learning environment. According to this theory, the instructor frames the information to be provided by context using prior relevant examples and participating in a social dialogue on the topic (Wrenn, 2015). The constructivist instructor job isn't to simply talk at their learners; rather, they should be providing opportunities to demonstrate understanding. Applied to the framework of this paper, the instructor demonstrates lessons to a class lesson online, via the appropriate channel, such as demonstrating how to structure an English language essay properly, how properly enunciate new vocabulary, or provides a framework in which learners can collaborate and develop a presentation of their skills. The instructor should provide the content, exercises, and prompts that allow the learners to construct their own knowledge that connects with their prior knowledge and experience. Modern technology provides far more integrated tools that can be directly deployed to the collaborative constructivist methodology.

Collaboration tools (such as Google Docs, Padlet, Microsoft Teams, e-Learning, Zoom, Loom, Google Classroom, and Schoology) are web tools that provides the means and the space for both learners and instructors to share, edit, interact with, and collaborate on a variety of documents and files. According to Altun (2015), technology-based instruction offers a solution to a problem that has plagued education professional for a long time, how to provide a variety of ways to interact with the material without going over the time allotted to hold your lessons. With all of the different technological materials, learners are able to choose between different tools that offer different advantages. This does, in turn, mean that an instructor should be vigilant of ensuring that they are utilizing technology that provides this variety and that the technological offerings suits the learners' needs. In addition, instructors must integrate the EdTech in such a way as to ensure that the learners' time is being spent exploring meaningful material and that the learner has the opportunity to participate in authentic experiences that promote engagement. 
As previously discussed, the use of technology in classrooms can encourage learners to take a more active role in their own learning through collaborative and constructive online opportunities. Innovations in EdTech, like online tools, helps instructors to redesign the learning process and the way teaching is approached in educational environments. The research cited throughout this paper consistently concludes that this would be beneficial to learners and improve their language acquisition. By using EdTech in English language education, the study of Cote Parra (2015) showed that technology-supported learning environments provide language learners with a dynamic and more engaging way of learning and fosters student interaction. Watson, Murin, Vashaw, Genim, \& Rapp (2012), like many others cited before them also provides evidence that online learning can result in improved student outcomes. Moreover, online teaching best practices specifically includes instruction that utilizes multiple resources and provisions to provide timely and constructive feedback. This author's own classroom experience further supports this theory that the language learners' achievements improve through thoughtful and thorough integration of EdTech. The English reading and writing learners were not only able to meet the expectations developed from more traditional methodology, but to exceed the expectations previously held. Though further research is always welcome, a combination of personal anecdotes and significant research by other parties makes it hard to refute the viability and success of modern technology facilitating online language learning.

\section{Benefits and Limitations of Using Technology in Language Classroom}

Students are not the only ones to benefit from the integration of technology. Instructors can also have more fun with their teaching as they no longer must teach things the same way that they have been traditionally doing. As has been made evident from this author's own personal experience, the integration of technology for well-designed and properly prepared activities tends to increase the motivation of both instructors and learners. This, by its very nature, leads to improved performance and better learning results. Technology can also play an important role in the process by enhancing timely understanding, as students can use and review the material that is most beneficial to them as they wish. This ultimately enables learners to acquire knowledge more efficiently. In addition, instructors have been shown to perform more effectively when using modern technology as they are able to convey information in a variety of ways while they are teaching and they can automate some of the more tedious tasks. Jacqui (2015) supports this papers' claim on the technology in English language teaching; saying that the technology allows learners demonstrate independence, provides for the different needs of learners with different skillsets, and provides opportunities to learn by using resources that the learners are interested in. All of this comes together to help the learners build a foundation of strong content knowledge.

In addition, technology helps learners to develop many skills that will be useful in life beyond academia, including the creation of presentations, the ability to differentiate between reliable and unreliable sources on the internet, and the development of proper online etiquette. Many studies noted that technology use is of benefit to English language teaching and learning specifically (Costley, 2014; Alsaleem, 2014; Parvin \& Salam, 2015; Babacan \& Gunuc, 2017; Xiao, Liang, Li, \& Jia, 2017). The result from the instructor's assessment showed that technology benefits both autonomous and student-centered learning methods by increasing the level of responsibility the learner takes in their own education. A survey of the learners after the course revealed that the learners had a generally positive experience with online learning method. The learners posited that they gained more experience during the course technology integrated course than they had with prior, more traditional, courses.

The instructors additionally benefit from being able to use different EdTech tools to enhance traditional ways of teaching through virtual lesson plans, grading software, and online assessments. These tools can cut a lot of the busy work out of teaching and allows the instructor to focus more on their students. Additionally, the implementation of virtual learning environments in educational institutions can provide additional opportunities for educators to collaborate and share knowledge. In addition, the study of Alghasab (2020) suggested that using technology in the classroom propagates a change in the way learners' view education and can change the learning environment itself into one more conducive to promoting motivation and engagement versus the less individualized environment of a more traditional classroom.

While the benefits of promoting and implementing technology has been expounded upon in length herein, it would be arrogant to presume and present this as a new methodology without and limitations or drawbacks. First, the study of Imad (2015) explained that the instructors themselves may be one of the largest barriers to the implementation of an EdTech integrated class. Unfortunately, his study showed that many teachers themselves were not competent enough to use, much less implement, a technologically integrated class effectively. Second, Purhosein et al. (2015) states that the lack of IT support in schools to repair computers, internet connections, and troubleshoot various other issues would make it a challenge to even begin integrating a technology-based system in the educational organization. Next, Mollaei (2013) reported that the low number of class hours would likely pose a problem. Finally, Mohamed (2014) supported the point made by Imad, in that instructors tend to have 
insufficient experience with technology, lack confidence, lack facilities, and lack the training to properly facilitate a technologically integrated class.

In summary, while the classroom implementation of EdTech in general and online learning technology specifically does provide both advantages and disadvantages, this paper posits that the realizing the advantages is worth confronting the limitations inherent in this technology. These advantages are no less prevalent for the acquisition of language, and in fact, some benefits are especially strong for the language learning process. Even were we to be reluctant to follow these suggestions in normal times, the reality that has been imposed on us by COVID-19 has forced our hands. It is no longer a matter of IF we should implement technology; rather, it is a matter of what aspects of technology and how to implement it. Nonetheless, the disadvantages still deserve continued investigation and educators should do their best to both be aware of and circumvent (where possible) these issues. This author's observation during the technologically integrated class with a total 15 sessions, is that the learners had a positive experience with the technology, it was beneficial for the learners to study by themselves and the technology prompted the learners to search for more of their own information as it related to their studies. The learners appear to have gained more experience and knowledge both inside and outside classroom than they would have in a more traditional setting. More research being conducted, especially regarding viable methods to overcome the limitations in technology integration and create even more successful models of technology-based instruction.

\section{Suggestions for the Successful Integration of Technology}

In this paper, technology integration or the integration of technology has been an oft used phrase. Herein the integration of technology in the educational setting refers to the utilization and adaptation of technology to promote the instruction and apply specific technological devices to enhance the teaching and learning process. The process requires instructors to have sufficient technological knowledge to possess the ability to understand its pedagogical value to the learners. Technological devices and tools are already used in the classroom on a fairly regular basis, and the learners are comfortable with using a variety of similar tools in their daily lives. Learners have even used some of the proposed tools in their studies to show understanding of instructional content, without official technological integration. While many learners may be comfortable with many of the EdTech tools to be used, the technology must be appropriately introduced, explained, demonstrated and integrated. To do otherwise would be to start the course with some learners at an unfair advantage. In the Thai EFL class, for example, learners use Microsoft Teams, Zoom, e-Learning, Line, e-mail, and the Google Classroom applications. They can study and practice either collaboratively or by themselves - both in and out of the classroom. The learners use the 4Cs (Creativity, Critical Thinking, Communication, and Collaboration) as they learn.

Why is technology integration important? The most immediate reason is that the pandemic does not allow for more traditional environments to safely occur; however, there are a myriad of more permeant reason to integrate technology into the education system. There is an increasing need for self-directed learning and to teach the ability to perform a variety of tasks independently. The learners are better equipped to set their own goals, critically think about and analyze topics, pursue logical reasoning, and use creativity in their efforts when the tools of technology are there to assist. There is an emergent need for strong communication skills, both for interpersonal and in presentation and in both academia and in a more corporate environment. Furthermore, as discussed on several occasions, technology aids motivation and promotes increased engagement with the learning materials. If implemented properly, learners should work in more depth with the content, and be able to move beyond knowledge acquisition and comprehension and apply and analysis related information as it becomes available.

To effectively integrate technology in the classroom instructors should first select what content they intend to teach, and then they can decide which technological tools could be best taught using the proposed content area. After the general content and the appropriate tools have been determined, instructors should choose a specific lesson in that content area that could be enhanced or taught through the technological devices. Teachers shouldn't immediately jump to using programs that they aren't comfortable with; their first lessons should be developed with a software application they know well and are comfortable with. After that, the technologically integrated lesson should be tested before extending it to many classes or repeating it. The final step is to, to apply what was learned in and conduct ongoing assessment of the lesson to ensure that any issues can be addressed before they become more seriously problematic. When technology integration in the classroom is seamless, thoughtful, and well prepared, students become more engaged, begin to take more control over their own learning, and have a tendency to enjoy the learning process as a whole more.

Integrating technology into the classroom, when done with an understanding of the varied ways in which people learn, is an effective way to reach learners of all learning styles. It provides the learners the tools and ability to 
enhance their interactions with their classmates and instructors by encouraging collaboration. Combining new technology, like virtual reality, with traditional teaching methods to provide students with a panoramic experience of a place they have never visited is one example of how new technology can enhance the learning experience and make it feel more "real". Technology transforms the learning experience by increasing the amount of methods the learner can interact with the content. This allows for more control and more personalized methods to attain knowledge. This can be used to realize a variety of educational objectives: from learning how to code to learning how to better collaborate across teams and with their instructors. Technology empowers learners to be more creative and be more connected (Mareco, 2017). Furthermore, when done correctly, technological integration guides students towards greater understanding of all concepts covered in class. To keep learners engaged and interested in formal education, teachers should always be on the lookout for new strategies and new tools that can be implemented to enhance the educational experience.

As previously mentioned, integrating technology into education assists the learners to build the competencies that they need for the future. As such, the implementation of technology in the educational setting should be the standard, not the exception. A lack of implementation should only be permissible when there are other outstanding factors that make it unfeasible. As technology helps change the learner/teacher roles and relationships; as students take more responsibility for their learning outcomes; teachers will take up the mantle of guides and facilitators of knowledge. Since Thai EFL learners are already studying in a digital world, it is important that technology integration does not fail to provide the opportunities that they deserve from their education. The learners need learning experiences to be relevant and meaningful. For the material to continue to be both relevant and meaningful, the acquisition, demonstration, application, and communication of information must meaningfully incorporate more technology. To effectively meet the learning styles and challenges of the present and future learners, instructors must quickly adapt to changing technology and be comfortable with learners who seem to effortlessly multitask using the technology-rich environment they were born into. Teaching and learning environments must not fall into archaic disrepair and fail to meet the reasonable needs of both the modern environment and modern learners.

\section{Conclusion}

With the continuation of the COVID-19 pandemic, the implementation of technology into the classroom transcends the realm of helpfulness to that of the necessary. To ignore this new reality, we find ourselves in is not to simply fail to uphold the educator's duty to our learners' education, it is to jeopardize the very health and safety of the learner, the learner's family, and their community. COVID-19 has ensured that educators confront the reality that education technology needs to do more than deliver great content and engage students and teachers, it must provide a sanctuary for learners and teachers to thrive in safety. The integration of technology and need to prepare both learners and teachers in its use has become a high priority for all educational institutions. Technology provides interaction between teachers and learners when traditional interaction is dangerous. Technology provides comprehensible and measurable inputs and outputs, helps learners to develop critical thinking skills. Technology makes learning and teaching more student-centered and promotes the learners' autonomy. Technology helps learners to feel more confident while increasing learners' motivation to effectively learn a foreign language. Technology can give both instructors and learners remarkable resources, but those resources need to be understood and prepared appropriately.

Technology is already a predominant provider of entertainment, is it any wonder that the utilization of technology can make educational opportunities more fun, enjoyable, and accessible when content is properly conveyed in these new ways. EdTech is not some small oft overlooked business sector, it is a thriving sector of the economy and it should surprise nobody that EdTech provides a multitude of online and offline resources capable of improving the educational paradigm. Virtual lesson plans, grading software and online assessments can reduce workload allowing teachers to focus more time on what really matters, the students. Modern learning should involve modern philosophy and modern technology. It should be about collaborating with others, solving complex problems, critical thinking, developing different forms of communication and leadership skills, while improving motivation and productivity. Using the various types of technology in the classroom, allows both instructors and learners to develop skills essential for present day life. The young minds that are the responsibility of educators already pursue and engage with technology on a daily basis and in most aspects of their lives. It is time that educational facilities approach these young minds where they already thrive, in the realm of technology.

\section{References}

Ahmadi, R. M. (2018). The use of technology in English language learning: A literature review. International Journal of Research in English Education, 3(2), 115-125. https://doi.org/10.29252/ijree.3.2.115 
Alghasab, B. M. (2020). Flipping the writing classroom: focusing on the pedagogical benefits and EFL learners' perceptions. English Language Teaching, 13(4), 28-40. https://doi.org/10.5539/elt.v13n4p28

Alsaleem, B. I. A. (2014). The effect of "WhatsApp" electronic dialogue journaling on improving writing vocabulary word choice and voice of EFL undergraduate Saudi Students. Harvard: 21st Century Academic Forum Conference Proceedings. Retrieved from http://www.readwritethink.org/lesson_images/lesson782/Rubric.pdf

Altun, M. (2015). The Integration of Technology into Foreign Language Teaching. International Journal on New Trends in Education \& their Implications (IJONTE), 6(1). Retrieved from http://www.ijonte.org/FileUpload/ks63207/File/03a.altun.pdf

Arifah, A. (2014). Study on the use of technology in ELT classroom: Teachers' perspective. M. A. Thesis, Department of English and Humanities, BRAC University, Dhaka, Bangladesh.

Babacan, N., \& Gunuc, S. (2017). Technology integration in english language teaching and learning. The Journal of Teaching English for Specific and Academic Purposes, 5(2), 349-358.

Costley, K. C. (2014). The positive effects of technology on teaching and student learning. Arkansas Tech University.

Cote Parra, E. (2015). Engaging Foreign Language Learners in a Web 2.0- Mediated Collaborative Learning Process. Profile Issues in Teachers Professional Development, 17(2), 137-146. https://doi.org/10.15446/profile.v17n2.47510

Crane, E. (2012). Using Web 2.0 and Social Networking Tools in the K-12 Classroom. Chicago: American Library Association.

Disli, Ö. (2012). Improving writing skills through supplementary computer-assisted activities. Gazi University.

Donaldson, L. (2014). Integrating Web 2.0 Learning Technologies in Higher Education: The Necessity, the Barriers and the Factors for Success. AISHE-J: The All Ireland Journal of Teaching \& Learning in Higher Education, 6(3), 1-22. Retrieved from http://www.culi.chula.ac.th

Gençlter, B. (2015). How does technology affect language learning process at an early age? Procedia - Social and Behavioral Sciences, 199(3), 311-316. https://doi.org/10.1016/j.sbspro.2015.07.552

Hockly, N. (2015, July). Developments in online language learning. ELT Journal, 69(3), 308-313. https://doi.org/10.1093/elt/ccv020

Huang, C. S., Yang, S. J., Chiang, T. H., \& Su, A. Y. (2016). Effects of situated mobile learning approach on learning motivation and performance of EFL students. Journal of Educational Technology \& Society, 19(1), 263. Retrieved from https://search.proquest.com/docview/1768612513?pq-origsite=gscholar

Imad, M. (2015). The perceptions of students and teachers about the benefits of and barriers to technology aided EFL. Journal of Literature, Languages and Linguistics, 13, 85-99. Retrieved from www.iiste.org/Journals/index.php/JLLL/article/view/24820/25423

Jacqui, M. (2015). 13 Reasons for Using Technology in the Classroom. Retrieved from https://www.teachhub.com/13-reasons-using-technology-classroom

Kasteen, J. (2014). Global trends in foreign language demand and proficiency. In ICEF Monitor. Retrieved from $\mathrm{http}: / /$ studenttravelplanningguide.com/global-trends-in-foreignlanguagedemand-and-proficiency

Lamb, M., (2017). The Motivational Dimension of Language Teaching. Language Teaching, 50(3), 301-346. https://doi.org/10.1017/S0261444817000088

Mareco, D. (2017). 10 reasons today's students need technology in the classroom. Retrieved from https://www.securedgenetworks.com/blog/10-reasons-today-s-students-needtechnology-in-the-classroom

Mofareh, A. A. (2019). The use of technology in english language teaching. Frontiers in Education Technology, 2(3), 168-180. https://doi.org/10.22158/fet.v2n3p168

Mohaded, M. (2014). Using technology in EFL/ESL classroom. International Journal of Humanities and cultural studies, l(2). Retrieved from https://www.ijhcs.com/index.php/ijhcs/article/view/29

Mollaei, F. (2013). Teachers' perceptions of using technology in teaching EFL. International Journal of Applied Linguistics \& English Literature, 2(1), 13-22. https://doi.org/10.7575/ijalel.v.2n.1p.13 
Noytim, U. (2010). Weblogs enhancing EFL students' English language learning. Procedia Social and Behav--ioral Sciences, 2, 1127-1132. https://doi.org/10.1016/j.sbspro.2010.03.159

Online Purdue. (2020). How has technology changed education? Retrieved from https://online.purdue.edu/blog/education/how-has-technology-changed-education

Online Teaching Tools and Resources. (2015). Yale Centre for Language Study. Retrieved from https://cls.yale.edu/faculty/resources/online-teaching-tools-and-resources

Pamintuan, F. C., Mallari, D., Garcia, N., Galang, J., \& Buduan, M. R. (2018). The use of wechat application on cfl learners' vocabulary acquisition. TESOL International Journal, 13(4), 26-38. Retrieved from https://eric.ed.gov/?id=EJ1244122

Parvin, R. H., \& Salam, S. F. (2015). The effectiveness of using technology in English language classrooms in government primary schools in Bangladesh. FIRE: Forum for International Research in Education, 2(1), 47-59. https://doi.org/10.18275/fire201502011049

Patel, C. (2013). Use of multimedia technology in teaching and learning communication skill: An analysis. International Journal of Advancements in Research \& Technology, 2(7), 116-123. Retrieved from http://www.ijoart.org/docs/Use-of-Multimedia-Technology-in-Teaching-and-Learning-communication-skill .pdf

Pourhosein, A., Banou, N., \& Zabihniaemran, A. (2015). What are the barriers in the use of computer technology in EFL instruction? Review of European Studies, 7(11), 213-221. https://doi.org/10.5539/res.v7n11p213

Pourhossein Gilakjani, A. (2014). A detailed analysis over some important issues towards using computer technology into the EFL classrooms. Universal Journal of Educational Research, 2(2), 146-153.

Pourhossein Gilakjani, A. (2017). A review of the literature on the integration of technology into the learning and teaching of English language skills. International Journal of English Linguistics, 7(5), 95-106. https://doi.org/10.5539/ijel.v7n5p95

Pourhossein Gilakjani, A., \& Sabouri, N. B. (2017). Advantages of using computer in teaching English pronunciation. International Journal of Research in English Education (IJREE), 2(3), 78-85. https://doi.org/10.18869/acadpub.ijree.2.3.78

Song, D., \& Bonk, C. J. (2016). Motivational factors in self-directed informal learning from online learning resources. Cogent Education, 3(1), 1205838. https://doi.org/10.1080/2331186X.2016.1205838

Suminar, A. (2020). Dampak covid-19 terhadap ekonomi global 2020. surabaya: suarasurabaya.net.

Sun, A., \& Chen, X. (2016). Online education and its effective practice: A research review. Journal of Information Technology Education: Research, 157-190. https://doi.org/10.28945/3502

Surjono, H. D. (2015). The effects of multimedia and learning style on student achievement in online electronics course. Turkish Online Journal of Educational Technology TOJET, 14(1), 116-122. Retrieved from https://eric.ed.gov/?id=EJ1057334

Swan, K. (2019). Research on online learning. Research Center for Educational Technology, Kent State University. https://doi.org/10.24059/olj.v11i1.1736

Ur un, M. F. (2016). Integrattion of technology into language teaching: A comparative review study. Journal of Language Teaching and Research, 7(1), 76-87. http://doi.org/10.17507/j1tr.0701.09

Watson, J., Murin, A., Vashaw, L., Gemin, B., \& Rapp, C. (2012). Keeping Pace with K-12 Online and Blended Learning. Evergreen Education Group. Retrieved https://kpk12.com/cms/wp-content/uploads/KeepingPace2012.pdf

Wrenn, V. (2015). Effects of traditional and online instructional models on student achievement outcomes. Doctoral Dissertations and Projects. Retrieved from https://digitalcommons.liberty.edu/doctoral/1135

Xiao, Y., Liang, Z. L., Li, Q., \& Jia, R. J. (2017). Exploring the feasibility of video-mediated listening test in a Nation-wide proficiency english examination in china. TESOL International Journal, 12(2), 1-16. Retrieved from https://eric.ed.gov/?id=EJ1247808

\section{Copyrights}

Copyright for this article is retained by the author(s), with first publication rights granted to the journal.

This is an open-access article distributed under the terms and conditions of the Creative Commons Attribution license (http://creativecommons.org/licenses/by/4.0/). 